\title{
Globalization and the Third Research Program of Multiple Modernities ${ }^{2}$
}

\begin{abstract}
Shmuel N. Eisenstadt has fundamentally modified the classical theory of modernization. Over the course of his work, which is connected with the changes of sociological theory since the 1950s, he has executed a turn from the comparative analysis of institutions to the research program of comparative civilizations. The research program of multiple modernities has emerged out of this attentional shift coming from the First Research Program 1986, which led to "multiple modernities" and to the Second Research Program 2003. A key milestone was the critique of the theory of structural differentiation as the main process underlying the socio-structural evolution of societies; this began with The Political Systems of Empires (1963), along with the development of convergence theories of modernization, which have had impact on contemporary sociological theory beginning with that same book. In the meantime, the research program of multiple modernities now continues into the Third Research Program of Multiple Modernities, Membership, and Globalization 2016 and its implementation (Preyer and Sussman, 2016a, b). Firstly, I will show how the program seeks
\end{abstract}

1 Professor of Sociology, Editor-In-Chief of "ProtoSociology: An International Journal of Interdisciplinary Research and Project”, Goethe-University Frankfurt am Main, preyer@em.uni-frankfurt.de.

2 Contribution to Congress Legacies of Shmuel Noah Eisenstadt: From Philology to Sociology, den Vincenzo Cicchelli and Madalina Vartejanu-Joubert (organizer) at the "Societes Plurielles”, Université Sorbonne-Paris-Cité, vom 26.-27. Januar 2016, Paris, France. 
to sketch an updated vision of the theoretical systematization of research on globalization since the 1990s. Secondly, I will go on to sketch the foci of research within the Third Research Program in our era of globalization; finally, I shall outline some consequences of changes in the research situation within sociological theory.

\section{Keywords:}

multiple modernities, sociology of membership, globalization, hybridization, creolization, multi-culturalism, global studies, postmodern society, development theory, collective identities

\section{INTRODUCTION}

The term "globalization” encompasses a variety of approaches within sociology, with regard to what the term refers to. Even 25 years after Robertson's first globalization book, the discussion around globalization continues (Robertson, 1992). A sociology of globalization fails when it comes to the unification of points of observation. Although single academics have established insights in the structural change of societies along various dimensions, the sociology of globalization lacks an integrated research program. ${ }^{3}$ We would do well to speak of "theory" in this context as consisting in research programs (Lakatos), rather than to characterize it as a theoretical deductive axiomatization (following Eisenstadt and Schluchter). ${ }^{4}$ The absence of such an integrated research program results in a variety of observation points of view, traditional sociological concepts, and theories as well as rhetorical political evaluations of the various real-world interest groups in the first place. Methodological procedures cannot close this gap. A propos of this we should first ask, "What are the boundaries of society (-ies), and of societal

3 The term "sociology of globalization" goes back to Sassen 2007. Reference problem is a contribution to sociological theory. On the sociology of globalization, see Preyer 2017 (second edition) 1: on the dimensions of globalization, III Cap. IV.

On the research project of a sociological theory, see, generally, ProtoSociology www.protosociology.de. Also, see Academia.edu under Gerhard Preyer units “Globalization, Modernization, Multiple Modernities”, “Sociology of Membership, Sociological Theory”, Preyer 2014c. Lectures: Sociology of Membership, Raley, Preyer 2010, Preyer 2016d. On new research touching on modernization in the global scene, see, ProtoSociology (26) 2009, (27) 2011, (33) 2016.

4 Schluchter 2006, 1, see also about, with reference to Homans, Parsons 1977a. 
communication? Where do they influence/interfere each other? And what are the results of this interaction?" 5

Studies of globalization often operate on a functional level: for example, look at studies on the economic, scientific, political, and legal systems involved in globalization. Such observation points of view allows us to discover the reforming structure of societal subsystems, and imagine the remaining set of social order. But for an analysis of globalization, such a research design is not fruitful enough, because it does not take into account the changed dimension of cultural globalization, the structure of communication initiated by modern technologies, and the reforming of ascriptive collective identities and solidarities. Due to this, a sociology of globalization requires a more dimensional resystematization. This can be implemented methodologically.

\section{SOCIOLOGY OF GLOBALIZATION: CONCEPTS AND STUDIES}

Sociological research and its current foundations can be sorted into five main approaches: homogenizer, heterogenizer, in-between models (Roberson's glocalization, hybridization), ${ }^{6}$ multiple modernities, and global-studies (Nederveen Pieterse, Robertson, 1995, pp. 25-44; Featherstone and Lash, 1995, pp. 3-5).

1. "Homogenizers" interpret globalization as a general unification of social exchange into the framework of a world society; these theorists often support this interpretation with claims about social norms, law, and general standardization. They argue that economic standards have increasingly been implemented over a variety of regional societies, leading to cultural unification: "Coca-Cola culture”. This category, grosso modo, includes a diverse group of scholars: for example, Giddens, Wallerstein, functionalists such as sociologists in the tradition of Parsons and Luhmann; as well as Keynesian welfare sociologists.

2. "Heterogenizers", in contrast, emphasize the social distinguishing characteristics of world society (for example, of cultural and religious identities, and of differ-

5 See, ProtoSociology (15) 2001.

6 The cultural definition of hybridization goes back to Rowe and V. Schelling 1991. They define "Hybridization" as "the way in which forms become separated from existing practices and recombine with new forms of new practices," 231, on an extension of the definition as structural hybridization, see also, Nederveen Pieterse 1995, pp. 45-68, 2004. He emphasizes, “This principle can be extended to structural forms of organization,” p. 49. 
ing law traditions), despite the compaction of communication and the increasing trend of migration in recent years. These 'heterogenizers' are interculturalists (for example, Said, Bhabba, and Hall), reflexive anthropologists (for example, Clifford, Marcus), and cultural studies sociologists more generally.

3. The "in-between account" of Robertson's glocalization and the hybridization in turn focus on the observation of reciprocal influences of global and local processes in modernization, which tend to establish new (hybrid) social entities, entities which exist beyond universalism and particularism.

4. The multiple modernities research program offers a new and different approach for analyzing globalization, which takes into account both glocalization and hybridization (Nederveen Pieterse, 2004, 2007). The hard core of the research program is this: modernization does not bring out an "evolutionary potential common to all societies", and particular paths of modernization cannot be generalized. This program combines a general sociological approach with historical structural preconditions - that is, it uses the relationship between "agency-structure" and "culture-social structure" as a framework for the analysis of the control of the flow of free resources. This sophisticated approach allows us to identify and systematize commonalities and differences that exist between types of modernization, as well as the influence of globalization writ large. ${ }^{7}$

5. The research program of "global studies" (Nederveen Pieterse) has taken into consideration the hybridization view that exists in the multiple modernities research program of Eisenstadt, because from the "global studies" view there exists no unified pathway of modernization to account for the career of Western modernity in the institutions and organizations of diverse nations or regions (for example, China, Japan, and India). Within the global studies research program, we find an analysis of the development progress of East Asian society in comparison to the

7 On the history and systematization of Eisenstadt's sociology, see, Preyer 2011, 2004. On Eisenstadt's sociology, see, for example, Marangudakis 2016, Ben-Rafael and Sternberg 2005, Ben-Rafael 2012. On the "constitutive basic frame of reference" of the semantic map, Preyer and Sussman 2016a, pp. 1-47.

On the particular pathway of China's modernization, see, Preyer and Krauße 2014b, Krauße 2015. It is to be recommend also with respect to the relationship between China and the United State of America, for example, Kissinger 2012, Nye 2015. Kissinger also describes relevant observations on the Chinese social construction. ProtoSociology (28) 2011, (29) 2012. On further research on China, see, Academia.edu under Gerhard Preyer, unit: “China’s Modernization”. On Latin America, Bokser Liwerant 2016. 
societies of Chile, Argentina, Russia, and the West in general. Nederveen Pieterse's turn is that we may recognize real-modernities in various different societies as being mixed formations, in that they straddle both past and present, as they import and translate styles and customs from other cultures - thus renewing the concept of "society" and "societies". 8

Should we mention that sociological theory is coming up against a serious problem regarding what globalization does, means, and is? Even the very word "globalization" itself is misleading, if we take that word's literal meaning for our orientation. The semantic element "glob-" refers to a scale model of celestial bodies, in cartography. In ordinary language, the word "globe" normally means "earth". 9 The structural changes within subsystems and societal communication are not something that includes the (cartographic) "globe”. This model, "globalization", fits more into the modern conception of the world as "this earthly sphere, Spaceship Earth": a "Columbus-world” as the world of discovers and a "Leonardoworld" as the world of inventors. ${ }^{10}$ Therefore we have a terminological problem of sociological theory.

Among scholars in the area of globalization research there exists a theoretical consent that globalization is initiated by the shaping of technological change. This takes effect across all subsystems: the redefinition of the function of the state organization of the political system, the development of a global hybrid multiculturalism and postmodernism, and the shaping of new regionalization. The intermediary sector is modern communication technology. A general proposition of globalization resting on the single factor of technological change only falls behind the approach of Robertson-Glocalization and multiple modernities, because it would underestimate the structure of influences, and results of the evolutionary change of social order, for example, of the national state.

6. Our sixth modality is "creolization" and hybridization: this new syncretism is a further approach (Cohen, 2007; Hannerz, 1992; Axford, 2013, pp. 65-66). From the exposed views of the scholars of globalization there has emerged a fundamental question, which relates to the conception of sociological theory and humanities

8 Nederveen Pieterse 2009, 2013, 2014. On global studies, Axford 2012, 2013, 2014, 2016, ProtoSociology (26) 2009. On Nederveen Pieterse’s approach in general, Preyer 2009, Nederveen Pieterse and Kim 2012, on Nederveen Pieterse and Kim East Asia studies 2012, Preyer and Krausse, forthcoming.

9 The "globe" is not identical with the sociological concept of "environment".

10 Mittelstraß 1992. He distinguishes furthermore the Leibniz-world as the world of monad and the Humboldt-world as the world of language. 
in general. That is, whether the re-conceptualization of the family of man and humankind in respect to "identity", "hybridity" and "hybrid multi-culturalism" ("global mélange”, "decivilization”) is beyond the so-called classical theory of modernization and development theory. Classical modernization theory (development theory) has assumed the inevitable global spread of: 1 . the Western cultural value-system as a connection between "universalism and individualism, rationalism and instrumental activism"; 2. institutionalized individualism (the Durkheim/ Parsons tradition); 3. the welfare state (the so-called Keynesian society-model); and 4. the inclusion program of civil rights.

In particular, the turn of "re-conceptualization" is seen in questions of gender identity as a feature of globalization (On global multiculturalism, Nederveen Pieterse, 2007). Call that the re-interpretation of the marking of members of social systems in their social intercourse. This is focused on "creolization" - a "hybrid term" - as a deconstruction of the self-description of the human condition of the "Old European Tradition”, as Luhmann has called it. ${ }^{11}$

From the scientific system point of view creolization as global diffusion is "universal to apply". ${ }^{12}$ The process of creolization progresses in three steps:

1. The description of a position between two or more social cultures by a selection of some appropriated components, and the negation of some others;

2. thereby "new possibilities" are created, which "transgress and supersede parents culture"; and

3. if the force of hybridization and creolization succeeds, then a "creolizing world" will emerge, which constitutes a redefinition of human mankind (Cohen, 2007). Hannerz (1992) concludes that just this is the end of autonomous self-identification of members of a culture, because the definition of the situation of all social intercourse is changed by the flow of people, ideas, things, images, and economic resources.

Creolization and hybridization (new syncretism) go beyond Westernization and the homogenization of societal communication, that is, this model describes a posthegemonic situation of societal communication. This switched situation leads to

11 That means social systems and society as a system is not to be finalized with respect to human beings. We are as humans, that is, as a physico-mental (biological) entity, a part of the environment of social systems, but a necessary one. This does not contradict the Parsons theory of analytical action systems. Schelsky (1967) has also argued in a similar direction because the speech "on the whole human of everyday life experience” is for him a "fiction” and a "scientific superstition".

12 It is a Caribbean view on the world culture; another term is "orientalization" and "cultural syncretism”, see, on a summary, Nederveen Pieterse (1995). Old "Diffusionism” is well-known in the past as the "German school” in ethnology going back to Friedrich Ratzel. 
the continuation of the research program of "multiple modernities, membership, and globalization" and the resystematization of the "theory of globalization" (Axford, 2013).

7. Conclusion: The changed theoretical situation poses the fundamental question: is there one world society or world system only as might be created by functional differentiation (Luhmann, Rudolf Stichweh, Wallerstein), or a the so-called "world society" of a "societies of societies" (Hondrich, 2001, p. 141; Nederveen Pieterse Luhmann, 1975; Krawietz, 2009; Münch, 2009) as a differentiation of membership orders of social systems? This second possibility goes along with the idea that globality initiates different modernizations (Robertson). Eisenstadt's research program of the comparative analysis of civilization is to be interpreted as a turn to civilizations as membership orders and their hybrid forms.

From the empirical point of view, it is obvious that the theoretical question refers to problems that affect all social systems: for example, ecological problems, the transnational expansion of the economic system, the expansion of communication by digital New Media, migration, and fundamentalism.

An understanding of globalization could be approached by considering a factpattern provided by a Pakistani scholar:

An English Princess (Princess Diana) with an Egyptian boyfriend, uses a Norwegian mobile telephone, crashes in a French tunnel in a German car with a Dutch engine, driven by a Belgian driver; who was high on Scottish whiskey, followed closely by Italian paparazzi, on Japanese motorcycles, treated by an American doctor, assisted by Filipino para-medical staff, using Brazilian medicine, dies! (Nederveen Pieterse, 2004, p. 122) ${ }^{13}$

This example suggests that globalization is an effect of a multidimensional and networked process of social exchange (Preyer, 2017, on a multidimensional approach).

In the meantime, we require a new theoretical design for the so-called "sociology of globalization", and it may be that we have to give up the concept of globalization in sociological theory. Another fact is that the analysis of globalization has to take in the observer's (theorist's) point of view, that is, the system with reference to which 'globalization' is being analyzed, for example, from the

13 It is, for example, to consider what it means that the biggest "call centre" with a global service is located in the Philippines. On this, see Friedman (2006). 
economic or the political system. If we take this problem seriously, the observer (theorist) is also an element within the theory of globalization.

\section{THIRD RESEARCH PROGRAM OF MULTIPLE MODERNITIES}

\section{(A) STEP TO THE THIRD RESEARCH PROGRAM}

The turn to the Third Research Program of Multiple Modernities, Membership, and Globalization 2015 is motivated thereby that we observe very extensive changes in contemporary societies. This Program succeeds the Second Research Program 2003 on a higher and re-specified level of the research on multiple modernities. ${ }^{14}$ It is directed towards the new and different social changes caused by the dynamics within the global framework, not as a single entity, but as a network of social systems, which has already initiated new tensions between their socially interrelated units. The Program takes in changes of social structure in all subsystems of the societal communication, which are caused by globalization. Such changes are not an unification of the social intercourse, and do not result in a global village, but quite contrary to that, to hybridizations, fragmentation, and the change of collective identities by new social movements. All this has happened within a global societal framework, a selective medial observation, and is not at all caused by single different social structures only, for example, by societal subsystems, and migration.

The step to the "Third Research Program View" is reasoned by the switched situation of sociological theory:

1. there is no unified single world society, global civil society, or globally unified modernization,

2. Robertson's glocalization and multiple modernization restructure social systems in general; they thus replace the observation point of view of communication, social exchange, and restructuration (Antony Giddens) not only theoretically, but also in everyday life,

3. the distinction between traditional and modern (non-traditional) societies is to be given up (Eisenstadt, Nederveen Pieterse, 2016); therefore ascriptive membership and collective identities of different types do not disappear, and

14 On the "third research program" Preyer and Sussman 2016a b, Eisenstadt 2004 a, b on the “first research program 1986”, and the "second research program 2003”, ProtoSociology (24). 
4. social exchange does not unify societal communication, and thus there persists a "world society" (Luhmann) as a "society of societies" with different levels of membership order. ${ }^{15}$

A working hypothesis for further theoretical systematization and empirical research in particular on this structural problem of social integration could be:

* The societies in a global framework of the future will be borderless, differentiated horizontally in regions as well as vertically in levels of locality up to globality (Münch, 2002, 2011).

Therefore in respect to the sociological theory of social integration, a new version is required in the meantime to analyze this structural problem. Many facets of this theoretical development pose one central question:

* How is a borderless, horizontally, and vertically differentiated societal communication integrated by the varying inclusion and exclusion of members of social systems, for example, being included in domains of the economic system by employment or being excluded in domains of exclusion in slums and by lasting unemployment?

Many sociologists make the distinction between "social integration", that is, a social system which is closed by its membership condition through an inside/ outside differentiation (for example, kinship, social stratification, and associations), and through "systemic integration" as a negative integration, for example, the economic, political, and scientific system, and through "inclusion-exclusion", that is, the chance or entitlement for consideration of a person as a member of a social system. The problem of inclusion-exclusion is not one of participation in communication or of membership in organizations; rather, the level of the chance of consideration of a person is to be analyzed through the differentiation of the societal membership system, and through "solidary integration", that is, collective integration, for example, the welfare state and organizations such as unions and associations; these also implicate structural problems and the non-perfectibility of societal communication.

* Everything we know from systematization and empirical research about social integration indicates that we should not renew our view of the welfare state as

15 Another issue is "How do we integrate the changed social structure of contemporary societies in the history of the Western modernization and the functional differentiation and interpenetration of its societal subsystems?”. See, for example, for a summary, Axford 2013. 
being a reciprocal support of national solidarity, economic control, and economic growth. Social integration is not a final state. As such it is a "creative destruction" and a "destructive creation", as Schumpeter has argued (Schumpeter, 2006).

Schumpeter refers to economic development. Among German sociologists, for example, Münch (2002, 2009, 2011) and Willke (2001, 2002) have argued that the structure-forming effect is extended to a reinterpretation of the sociological theory of social integration. However, it should be noted that one of the main focuses of sociological theory is the analysis of the types of social stratification (traditionally, for example, the Parson-Münch Tradition: the problem of justified inequality) (Parsons, 1977b). The old stratification of modern Europe was described idealtypically, for example: 1. Great Britain: an estate differentiated community; 2. France: hierarchy of estates, classes; 3. Germany: hierarchic differentiated community, estate differentiation of classes, and stratification of community equality. In the meantime, European stratification has changed (Preyer, 2014a). Sociologically speaking, social stratification should not be systematized primarily as a dominated hierarchy of power, but rather as a prestige regulation, which facilitates communication and contact.

If we distinguish between different development routes of modernization (multiple modernities), we will find that the regulation of social integration in the "next society" is one of self-guidance within social systems (for example, by voluntary associations), and not by decisions of a social centre, which claims to prescribe what is "right and wrong" and to command generalized recognition (Drucker, 2001; Baecker, 2007).

The distinction between "differentiated horizontally by region" and "vertically in levels” is made by an observer. But taking in an observer does not mean that the presupposed social domain is empty; rather, it is observed using distinctions of relevance within sociological theory.

In sum: what we call "globalization" should be studied as an endlessly segmentary and stratificatory differentiation using a new "zone of interpenetration”, framework of communication, social observation, social exchange and organization-building. We do not yet have a significant theoretical description of this transformation in the research situation of sociological theory. But we have enough evidence to provide the foci of research. In particular, the so-called "theory of globaliziation", if there is one must be resystematized. ${ }^{16}$

16 On the changed research situation, for example, Ben-Rafael, Y. Sternberg 2016, Ben-Rafael 2011, Axford 2013, Münch 2011. 


\section{(B) REFRAMING}

In the past, the "constitutive basic frame of reference (semantic map)" of Eisenstadt's theoretical sociology was not (often) taken into consideration in the research program of multiple modernities. His view is that the semantic map is an evolutionary universal. This map is framed within the general social system-environment relationship from an observer's point of view in the domain of sociological theory, and has focused on main subjects of research in a comparative, structural, and historical perspective. ProtoSociology has given the semantic map a membershiptheoretical and membership-sociological reinterpretation (Preyer, 2016c).

The "semantic map" distinguishes between two "poles" (dimensions): firstly, the distinction between agency (creativity)-structure relationship, and secondly, the culture-social structure relationship. In the following, we shall assign the foci of the Third Research Program to these "poles".

\section{i. First Pole (Dimension)}

The first pole (dimension) is the type of cosmological order as a foundation of the cultural orientation of a society and its membership order, which is altered by the global diffusion of cultural and institutional patterns. This manifests in the agency (creativity)-culture relationship (on creativity and Axial civilization, Capdequi, 2015).

Classical Sociology has studied culture as consisting of communally shared values and convictions. Analyzing cultural globalization, however, leads us to a completely different approach to cultural phenomena. Sociological analysis does not focus on the diffusion process through the institutionalization of a system of cultural orientation, but rather through hybridizations and syncretisms, in particular, those brought about by organizational systems, which is a description from the sociological theory point of view (the background problem here is Giddens' double hermeneutics). With this in mind, the cultural dimension causes neither a universalization of values nor an individualistic pluralistic multiculturalism, but a new syncretism. It appears likely that the global diffusion of cultural and institutional patterns is an important feature of cultural orientation. This is a distance effect (Stichweh, 2000, pp. 254-56). As such, it is typical that the social units involved need not enter into any direct communication process.

This phenomenon leads to processes of indigenization of institutional and cultural patterns. It also relates to the transformation of the mass society into a segmented society, which has been brought about by the differentiation of information 
and marketing strategies using modern communications technologies. The contents of these messages are provided as a mixture adjusted to the desired audience by age cohorts, rites, and language (Ito, 1991). In respect to the changed cultural fabric, one could also speak of segmented culture. A segmented society and culture are no longer integrated by shared values and convictions or as a contra-factual orientation of the participants in communication.

This cultural, aesthetic, and even moral change initiates a competition of possibilities of interpretation, which leads to a new differentiation of experiences as it continues. Cultural products thus become available to a larger part of the population. A global market of cultural aggregations emerges, which compete with their interpretation of contents offered for members of social systems, which observe the other members under different features.

\section{ii. Focus of the Research}

We have switched in the meantime as a focus of research from the distinction of universalism-particularism to glocalization and hybridization (post-hybridization, creolization, new syncretism, and fragmentation of identities), as well as to conflicts in the contact between Axial and non-Axial civilizations in the global scene. The deeper background problem is that modern societies have not found a unified self-description.

We do not live in a "late modernity" (Giddens) in contrast to the "liberal modernity" and the "modernity of the welfare state (welfare economics)", as some sociologists have continually argued in the past. ${ }^{17}$ We observe within the social universe all over the world other, new cultural and symbolic programs, which have been set up: not only postmodernism, but also new syncretic and symbiotic arrangements of cultural symbolism in public places, for example, in architecture. The Japanese architect Kisho Kurokura, for example, speaks of a symbiotic time, which removes the intellectual Western culture as a progress in abstraction. Networking and segmental differentiation have a new relevance for restructuring the borderlines of social systems.

A relevant change can also be observed in the public sphere, because the societal self-observation of the members of social systems is being restructured by the new media (Castell, 1996, 1997, 1998). ${ }^{18}$ The tendency of these structural changes is

17 Nederveen-Pieterse, for example, emphasizes that Japanese society has modernized directly into a postmodern society without the typical Western path of modernization.

18 Castell's view of the "network society" may have its particular merits because the theore- 
that the public sphere is no longer organized by a civil society as in the classical period of modernization. ${ }^{19}$ The new media takes effect in the public sphere, and change its system of communication and symbolization. The world of simulations rules out reality (Baudrillard). In particular, we should analyze in which direction the reinterpretation of pluralistic and totalistic tendencies of modernity do change.

\section{iii. Second Pole (Dimension)}

The first pole (dimension) takes effect in the second pole: the culture-structuresocial structure relationship, that is, the conflicts and tensions that are generated within the structuring of the social interaction by the definition of the systemenvironment relation and its symbolic construction. The institutional processes and mechanisms manifest in the structure by continuous structuration (Giddens, 1984), the change of institutions, and the structure of subsystems (social structure) (on Giddens, Cohen, 1989). ${ }^{20}$

\section{iv. Foci of the Researches}

Contemporary societies have already switched in the meantime, in a global framework, to a situation beyond liberalism, welfare economics, and nation state. The main foci of research are:

1. the structural change of the functional sectors and their institutions (organization),

2. the structure of communication by network building, and the role of modern technologies,

3. the new social movement and changed collective identities, and

tical turn has changed our sociological description to a rebuilding of interaction systems, but this systematization that the network morphologies and network logic overtake all other forms of social interaction and organization is problematic because networks are always closely connected with a social frame. Therefore an additional framework is necessary for analyzing social networks. It should be mentioned, for example, that a person cannot simply enter in networks willingly.

19 The civil society as a model of social order is a typical American concept. It means the priority of social communities over the state organization.

20 Giddens' reference problem is a fruitful one, because structure is not only a deep structure that is in the time dimension without change. His claim in sociological theory is making a turn beyond subjectivism and objectivism. Structure and structuration are objective and the same time subjective. But Giddens' view that social structures is a result of power struggle is too one-sided. 
4. the function of collective identities in respect to the structure of social integration.

1. One focus of the research is the historical and contemporary switch of the leading social functional sectors and their institutions (organization), for example,

(a) in the political system: the change of sovereignty, citizenship, participation, and the reorganization of the Western welfare state,

(b) in the economic system: economic globalization (transnational division of labor), capital flows, migration, and global corporations, ${ }^{21}$ and

(c) in the legal system: new transnational courts, new legal institutions and new legal regulations, their consequences for national legal and political systems, and the persistence of the primary systems of law. ${ }^{22}$

2. A further focus is the change of the structure of communication by network building, the role of the modern technologies of communication, economic change, the political sector, and the restructuration of collective identities. A particular problem to consider is the analysis of the so-called "global institutions" ("organizations"), for example, political and military alliance organizations, cultural organizations, the fragmentation of hierarchies, and global investments.

3. Another focus of research is the weakening of the function of the Western national state and its cultural dominance, and of the governance strategies in the political system among states. At the same time, we observe new types of social movements, diasporas, and minorities in this situation. These are feminist, ecological, fundamentalist, and peace movements, which build a changed collective identity among their members. At the same time, communal religious movements emerge in the global scene that have anti-modern and anti-Western attitudes, as well as violent strategies against economic, cultural, and political globalization. There is a worldwide fight between members of autochthonous and commercialized Western collective identities. It is just this fight that shows how potentially fragile social order is, and how multiple new and changing institutional arrangements are being enhanced (Eisenstadt, 2012).

21 It should particularly be taken into account that empirical research gives us evidence that participation in the transnational economy is not a "race to the bottom" with increasing poverty, inner inequality, and declining social standards, and on the switched structure of the economic system, see, Münch 2009, 2011.

22 About the relevance of primary and secondary systems of law, see, Krawietz 2016. 
The shift to new collective identities (minorities, diasporas, for example, Muslim Chinese, and Korean, and Russian minorities in the new Baltic and Asian republics), and new social movements is significant in contemporary societies. In particular, it has consequences for the hegemonic model of the nation-state. The new social movements have changed their orientations to an ethnic, religious, and local setting. We find them in Western and non-Western societies, as well as simultaneously in Europe and the United States of America. This initiates a new "politics of identity", which shows itself in political communication.

It is significant in this context that the new social movement in the West among women and the ecological movement, as well as fundamentalist, communal religious, and similar movements shift to a local orientation and to a new particularism. In particular, the anti-globalization movement in the United States of America of the last decade can be characterized as such. The research focus here is on the destructive potentialities of the Jacobin component of modernity, which return in the religious orientations of contemporary social movements.

4. In respect to the research focus of the changed collective identities, the center of social systems, and its symbolization as a subject of sociological research, it should be mentioned that from Eisenstadt's point of view a society is a collectivity (that is, a membership order), which imposes constraints on its members as a prerequisite for participation in social intercourse. There is no society without the collective identity of its members. It is the shared point of view of the differentiation of membership. Collective identities are not residuals, as some theorists of modernization in the 1950s had long argued, for example, Myrdal (1998) and other contemporary sociologists. They do not disappear in the change of sociostructural evolution and modernization.

Eisenstadt's analysis of collective identities is not the traditional one. He does not describe such identities using natural properties; rather, he describes them as constructions and imaginary entities. Eisenstadt and B. Giesen have distinguished the primordial (such as gender, generation, kinship, territory, language, race), the civic (such as implicit and explicit rules, traditions, social routines), and the sacral/transcendent code (such as the relation of the collective subject to the sacred and sublime, defined as God, Reason or Progress) (Eisenstadt and Giesen, 1995; Eisenstadt, 2009).

The construction of collective identities and the selection of membership are not without continual tensions, conflicts, and contradictions. Sociologists analyze this as a self-awareness of the social, caused by the self-selection of social systems, and the recognition of their borderlines by their members. Collective identities 
and the mechanisms of their stabilization are labeled by the distinction between member and non-member (strangers) as their elementary distinction. In the West, the conflict between citizenship and membership of a primordial community, state and nation is a classical one. Collective identities, their construction, and re-interpretation are the link between structure, culture, and social structure. They constitute the manifestation of social order and charismatic activity, which are related to self-description of societal communication in respect to the systemenvironment relationship.

\section{CONSEQUENCES}

In conclusion, we can say that for updating the research situation, the leading foci of research are "globality”, "transnationalism”, “multiculturalization” ("hybridization”), and “de-civilization”, as Ben-Rafael and Sternberg (2016) have argued. Socio-structural change initiates changes and opposed processes not only in societal communication, but also in the membership conditions of social systems. These foci have already altered Western modernity because postmodernity and postmodernisms have taken effect in all societal sectors, changing the cultural orientation, and self-definitions of the members of social systems.

In particular, it should be mentioned that the so-called "globality" does not initiate a homogenous social structure. On the contrary, it is focused on internally conflicted relationships between local social systems and global processes, such as fundamentalism, economic processes, ecological questions, and the selfidentification of the members of social systems.

From this reframed point of view, it is fruitful to analyze the changed relationship between power, trust, and meaning as the basic problem of social order and its charismatic dimension. Tensions are particularly evident between institution building and decay as well as between creativity and the regulation of communication in respect to common commitments. We observe in the contemporary societies in political communication, and in the economic sector structural changes by the processes of globalization as well as by glocalization. This requires a new view to the changes of the collective identities, and the social interactions, to be connected with the historical component, which are continued, and modified in the social structure within these societies.

The Third Research Program of Multiple Modernities and Robertson-globalization have abandoned the paradigm of modernization as Westernization, as well as 
the dilemma of universalism-particularism. ${ }^{23}$ The turn goes deeper in sociological theory than many sociologists have assumed. From my point of view, the switch in sociological theory is justified by the structural changes coming from globalization, glocalization, and hybridization. This also has consequences for the re-description and re-interpretation of the Western processes of modernization.

Modernity is no longer a project, as some sociologists have argued. In sociological theory, we have continually been dominated by the self-description of modernization that originated in the intellectual history of the West of the $18^{\text {th }}$ and $19^{\text {th }}$ century, for example, by the description of the state-centered society, the civil society, the ideologies of the social movement, the paradigm of the division of labor, and the distinction between community and society.

In the meantime, many sociologists no longer re-interpret Western modernization as project rationalizing within the research program of multiple modernities. On the contrary: postmodernity without the self-descriptions of modernity since the $19^{\text {th }}$ century is in harmony with multiple modernity, because there is no unified pattern of modernization. Both multiple modernities and postmodernity describe and re-interpret theoretically the changes in social structures that began in the early 1960s. But one aspect needs to be mentioned. If plural modernity cannot be analyzed using the evolutionary basic assumption of the classical theory of modernization, then the expressions modernity, modernization, and modern change their meanings in sociological theory. It can be assumed that this change also manifests continuously in the common mind of all members of social systems.

To sum up: The Third Research Program of Multiple Modernities, Membership, and Globalization 2015 has a particular significance for the analysis of globalization. From its point of view, the expression "global modernity" is systematically misleading. The cultural, economical, political, and technological globalizations do not interact within a single global society or a world society. The theoretical consequence of the new version of the theory of modernization in respect to the sociological theory of contemporary society is that modernity is not singular, plural, and universal. Western modernity is a particular civilization, which is spread and shaped by the particular elites that bear it. In the continuation of its expansion, there does not emerge any general valid civilization. Eisenstadt's investigations on the expansion of modernity suggest that modernity is not an evolutionary pathway

23 On the initial turn of the correction of the universalism-particularism distinction: the two different views, Robertson 1992, Hannerz 1992; about the two turns and the resystematization of the sociological basic concepts, Friedman 1995, Turner 1990. 
to a global civilization. On the contrary, we live in a time of global modernities or a next society beyond modernity. It is not expected that Western modernization is happening again. ${ }^{24}$

\section{References:}

Axford, B. (2012). Mere Connection: Do Communication Flows Compensate for the Lack of World Society? [In:] Selbstbeobachtung der Modernen Gesellschaft und die neuen Grenzen des Sozialen. Festschrift für Gerhard Preyer, G. Peter and R.-M. Krausse (eds.),Wiesbaden: Springer/VS.

Axford, B. (2013). Theory of Globalization, Cambridge UK: Polity.

Axford, B. (2014). Interview on 'Theories of Globalization', Global Studies Association, (February 13).

Axford, B. (2016). The Multiple Modernities Debates as a Prospectus for Global Scholorship: More Opportunities then Dead-End? [In:] Varieties of MultipleModernities. New Design of the Research, G. Preyer and M. Sussman (eds.), Leiden: Brill.

Baecker, D. (2007). Studien zur nächsten Gesellschaft, Frankfurt a. M/Berlin: Suhrkamp.

Ben-Rafael, E. and Sternberg Y. (2005). Social Change: Contribution of S.N. Eisenstadt, Encyclopaedia of Sociology 9. Oxford.

Ben-Rafael E. (2012). Biographical Memoir of Shmuel N. Eisenstadt, Proceedings of the American Philosophical Society, 2012 (156/2).

Ben-Rafael E. (2011). Transnational Diasporas: A New Era or a New Myth?, ProtoSociology: Modernization in Time of Globalization II (27).

Ben-Rafael E. and Sternberg Y. (2016). With and Beyond Shmuel N. Eisenstadt: Transglobality [In:] Varieties of Multiple Modernities, G. Preyer and M. Sussman (eds.), Leiden: Brill.

Bokser Liwerant, J. (2016). Thinking Multiple Modernities from Latin America's Perspective: Complexity, Periphery and Diversity [In:] Varieties of Multiple Modernities. New Design of the Research, (G. Preyer and M. Sussman eds.), Leiden: Brill.

Capdequi, C.S. (2015). The Challenge of Creativity: A Diagnosis of our Time, ProtoSociology. Unit: On Contemporary Sociology.

Castell, M., The Information Age (3 Vols.) 1: The Rise of the Network Society, 2: Economy, Society and Culture, 3: End of Millenium, Oxford: Wiley-Blackwell 1996, 1997, 1998.

Cohen, J. (1989). Structural Theory: A. Giddens, and the Constitution of Social Life, London: Macmillan.

Cohen, R. (2007). Creolization and Cultural Globalization: The Soft Sounds of Fugitive Power, Globalization 4 (2).

Drucker, P.F. (2001). The Next Society: A Survey of the Near Future [In:] The Economists. November 3rd. In Drucker, Managing in the Next Society, New York: St. Martin's Griffin 2001. 
Eisenstadt, S.N. (1963). The Political Systems of Empires, New York: Free Press of Glencoe. Eisenstadt, S.N. and Giesen B. (1963). The Construction of Collective Identity, European Journal of Sociology, 1995 (36).

Eisenstadt S.N. (2004a). A Sociological Approach to Comparative Civilizations: The Development and Directions of a Research Program, The Harry S. Truman Research Institute for the Advancement of Peace, Department of Sociology and Social Anthropology, Jerusalem 1986, ProtoSociology (24).

Eisenstadt S.N. (2004b). Collective Identities, Public Spheres and Political Order in Modern and Contemporary Scene. Prepared by Tal Kohavi, Julia Lerner, Ronna BrayerGrab. A Research Program at the Van Leer Jerusalem Institute under the Direction of Professor S.N. Eisenstadt 2003, ProtoSociology: Shmuel N. Eisenstadt: Multiple Modernities - A Paradigma of Cultural and Social Evolution (24).

Eisenstadt S.N. (2009). Cultural Programmes, the Construction of Collective Identities and the Continual Reconstruction of Primordiality [In:] Neuer Mensch und kollektive Identität in der Kommunikationsgesellschaft, G. Preyer (ed.), Wiesbaden: Springer/VS.

Eisenstadt S.N. (2012). The Axial Conundrum. Between Transcendental Visions and Vicissitudes of their Institutionalizations: Constructive and Destructive Possibilities [In:] The Axial Age and Its Consequences, R.N. Bellah and Hans Joas (eds.), Cambridge, Mass.: Harvard UP.

Featherstone, M. and Lash S. (1995). Globalization, Modernity and the Spatialization of Social Theory: An Introduction In Global Modernities, M. Featherstone, S. Lash and R. Robertson (eds.), London: Sage.

Friedman, J., (1995). Global System, Globalization and the Parameters of Modernity [In:] Global Modernities, S. Lash and Roberston (eds.), London: Sage.

Friedman, T.L. (2006). The World is Flat. A Brief History of the Twenty-first Century. New York: Farrar, Straus and Giroux (second edition).

Giddens, G. (1984). The Constitution of Societies: Outline of the Theory of Structuration. Oxford: Polity Press.

Hannerz, U. (1992). Cultural Complexity. Studies in the Social Organization of Meaning. New York: Columbia UP.

Hondrich, K.O. (2004). Der kommunizierende Mensch - und seine Missverständnisse [In:] Der Neue Mensch, Frankfurt a. M./Berlin: Suhrkamp.

Ito, Y. (1991) Johoka as a Driving Force of Social Change, Keio Communication Review (12).

Kissinger, H. (2012). On China 3. World Politics-21. Century, New York: Penguin Group.

Krauße, R.-M. (2015). Hybridisierung Chinas. Modernisierung und Mitgliedschaftsordnung der Chinesischen Gesellschaft, Wiesbaden: Springer/VS Verlag.

Krawietz, W. (2009). Moderne Rechtstheorie als Theorie primärer und sekundärer sozialen Systeme des Rechts [In:] In Neuer Mensch und kollektive Identität in der Kommunikationsgesellschaft. In memoriam Karl Otto Hondrich (1937-2007), G. Preyer (ed.), Wiesbaden: Springer/VS.

Krawietz, W. (2012). Ausdifferenzierung des modernen Rechtssystems und normative strukturelle Kopplung [In:] Selbstbeobachtung der modernen Gesellschaft und die 
neuen Grenzen des Sozialen, (G. Peter and R.-M. Krauße eds.), Wiesbaden: Springer/ VS Verlag.

Krawietz, W. (2016). Multiple modernities in Modern Law and Legal Systems: Shmuel Eisenstadt's Grand Design and Beyond [In:] Varieties of Multiple Modernities, G. Preyer and M. Sussman (eds.), Leiden: Brill.

Luhmann, N. (1975). Die Weltgesellschaft [In:] Soziologische Aufklärung 2 (6 vols.). Aufsätze zur Theorie der Gesellschaft, Opladen: Westdeutscher Verlag 1975.

Marangudakis, M. (2016). Multiple Modernities and the Theory of Indeterminacy. On the Development and Theoretical Foundations of the Historical Sociology of Shmuel N. Eisenstadt, [In:] Varieties of Multiple Modernities. New Research Design, G. Preyer and M. Sussman (eds.), pp. 1-47. Leiden: Brill.

Mittelstraß, J. (1992). Leonardo-Welt. Über Wissenschaft, Forschung und Verantwortung, Frankfurt a. M./Berlin: Suhrkamp Verlag.

Münch, R. (2002). Offene Räume. Soziale Integration diesseits und jenseits des Nationalstaats, Frankfurt a. M./Berlin: Suhrkamp.

Münch, R. (2009). Das Regime des liberalen Kapitalismus. Inklusion und Exklusion im neuen Wohlfahrtsstaat, Frankfurt a. M.: Campus Publisher.

Münch, R. (2011). Das Regime des Freihandels. Entwicklung und Ungleichheit in der Weltgesellschaft, Frankfurt a. M.: Campus Verlag.

Myrdal, G. (1998). An American Dilemma: The Negro Problem and Modern Democracy (1944). New Brunswick NJ: Transaction.

Nederveen Pieterse, J. (1995). Globalization as Hybridization [In:] Global Modernities, M. Featherstone, S. Lash and R. Robertson (eds.), pp. 45-69. London: Sage.

Nederveen Pieterse, J. (2004). Globalization and Culture. Global Mélange. Oxford UK: Rowman \& Littlefield.

Nederveen Pieterse, J. (2007). Ethnicity and Global Multiculture. Pants for an Octopus. Lanham: Rowman \& Littlefield.

Nederveen Pieterse, J. (2009). Twenty-first Century Globalization: Global Sociology, [In:] Globalization and Emerging Societies. Development and Inequality, (J. Nederveen Pieterse, B. Rehbein eds.), New York: Palgrave Macmillan.

Nederveen Pieterse, J. and J. Kim, (2012). Globalization and Development in East Asia. London: Routledge.

Nederveen Pieterse, J. (2013). What is Global Studies?, Globalizations (10, 4).

Nederveen Pieterse, J. (2014). Global Studies: Have Catechism, Will Travel, Globalizations $2014(11,2)$.

Nederveen Pieterse, J. (2016). Multipolarity Means Thinking Plural: Modernities [In:] Varieties of Multiple Modernities. New Research Design, G. Preyer and M. Sussman (eds.), Leiden: Brill.

Nye, J.S. (2015). Is the American Century Over?. Cambridge UK: Polity Press.

Parsons, T. (1977a). On Building Social System Theory: A Personal History [In:] Social Systems and the Evolution of Action Theory, New York: Free Press.

Parsons, T. (1977b). Equality and Inequality in Modern Society, or Social Stratification Revisited [In:] Social Systems and the Evolution of Action, pp. 321-380. New York: Free Press. 
Preyer, G. (2004). Introduction: The Paradigma of Multiple Modernities, ProtoSociology (24): Shmuel N. Eissenstadt: Multiple Modernities. A Paradigma of Cultural and Social Evolution (Collected Article) (24).

Preyer, G. (2004). 3. Globalisierung und Multiethnizität. Jan Nederveen Pieterses Beitrag zur Analyse struktureller Evolution [In:] Gesellschaft im Umbruch (2 vols.), Bd. 1: Jenseits von National- und Wohlfahrtsstaat, Frankfurt a. M.: Humanity Online.

Preyer, G. (2011). Zur Aktualität von Shmuel N. Eisenstadt. Einleitung in sein Werk, Wiesbaden: Springer/VS.

Preyer, G. (2014a). Kollektive Identität Europas und seine politische Integration, Rechtstheorie (4).

Preyer, G. and Krauße R.-M. (2014b). Chinas Power-Tuning. Modernisierung des Reichs der Mitte, Wiesbaden: Springer/VS.

Preyer, G. (2014c). Lectures: Sociology of Membership. Academia.edu under Gerhard Preyer units Sociology of Membership, Sociological Theory.

Preyer, G. and Sussman M. (2016a). Introduction on Shmuel N. Eisenstadt's Sociology:

The Path to Multiple Modernities [In:] Varieties of Multiple Modernities. New Research Design, G. Preyer and Sussman M. (eds.), Leiden: Brill.

Preyer, G. and Sussman M. (2016b). (eds.),Varieties of Multiple Modernities. Research Design. New Research Design, pp. 1-47. Leiden: Brill.

Preyer, G. (2016c). Struktur und das Semantic Map. Zur soziologischen Theorie Shmuel N. Eisenstadts (Essentials). Wiesbaden: Springer/VS.

Preyer, G. (2016). Una Interpretatión de la Globalization. Un Giroenla. Theorí Sociologica (Interpreting Globalization: Switch in Sociological Theory), Mexican Journal of Political Science, Revista Mexicana. (Num. 226).

Preyer, G. (2016). Soziologische Theorie der Gegenwartsgesellschaft (3 vols.), Bd. 1: Mitgliedschaftstheoretische Untersuchungen, Bd. 3: Mitgliedschaft und Evolution, Wiesbaden: Springer/VS (second edition).

Preyer, G. (2016). Academia.edu under Gerhard Preyer units Globalization, Modernization, Multiple Modernities.

ProtoSociology (2001). Sociology of Borderlines: Social Process in Time of Globalization, G. Preyer and M. Bös (eds.), (15).

ProtoSociology (2009). Modernization in Times of Globalization I, (26).

ProtoSociology (2011). Modernization in Times of Globalization, (28).

ProtoSociology (2011). China’s Modernization I.G. Peter, R.-M. Krauße (eds.), (28).

ProtoSociology (2012). China’s Modernization II.G. Peter, R.-M. Krauße (eds.), (29).

ProtoSociology (2016). The Borders of Global Theory-Reflections from Within and Without, B. Axford (ed.), (33).

Preyer, G. and Krauße R.-M. (Forthcoming) Globalization, Differentiation, and Membership Order. Jan Nederveen Pieterse Research Program focused on East Asia.

Raley, Y. and Preyer G. (eds.) (2010). Philosophy of Education in Era of Globalization, New York: Routledge.

Robertson, R. (1995). Globalization: Social Theory and Global Culture, London: Sage 1992. 
Robertson, R. (1995). Glocalization: Time-Space and Homogeneity-Heterogeneity [In:] Global Modernities, M. Featherstone, S. Lash and R. Robertson (eds.), London: Sage. Rowe W. and Schelling V. (1991). Memory and Modernity. Popular Culture in Latin America, New York: Verso 1991.

Sassen, S. (2007). A Sociology of Globalization. New York: W.W. Norton.

Schelsky, H. (1967). Ortsbestimmung der deutschen Soziologie (1959). Düsseldorf-Köln: Eugen Diederichs Publisher (third edition).

Schluchter, W. (2006). Grundlegungen der Soziologie. Eine Theoriegeschichte in systematischer Absicht (2 vols.), 1. Tübingen: Mohr Siebeck.

Stichweh, R. (2000). Die Weltgesellschaft. Soziologische Analysen. Frankfurt a. M./Berlin: Suhrkamp.

Schumpeter, J. (2006). Theorie der wirtschaftlichen Entwicklung (1912). Hrsg. von J. Röpke, O. Stiller, Berlin: Duncker \& Humblot (new edition).

Willke, H. (2001). Atopia. Studien zur atopischen Gesellschaft. Frankfurt a. M./Berlin 2001. Willke, H. (2002). Distopia. Studien zur Krisis des Wissens in der modernen Gesellschaft, Frankfurt a. M./Berlin. 